\title{
Effects of Motivating to Sustain Commitment of the Sales Professionals
}

\author{
Sayanjit Guha, Ph.D. Student \\ Faculty of Management, University of Warsaw, Poland \\ Ul. Szturmowa 1/3, 02-678, Warszawa \\ E-mail: sayanjitguha@gmail.com
}

Received: 20 June 2016 / Revised: 8 August 2016 / Accepted: 18 August 2016 / Published online: 6 October 2016

\begin{abstract}
Motivation is an important tool which can have a significant impact to improve the performance of employees in any organization and in the current competitive world, employees' commitment is crucial in achieving the organizational goals. The current research is aimed at examining the role played by motivation in sustaining the commitment of sales professionals. Primary data has been collected among 100 sales professionals using the close-ended questionnaire. For the analysis purpose both descriptive and inferential analysis has been conducted. The findings from the analysis show that most factors included in the model to measure the motivation show a significant and positive impact. Similarly the coefficient for organizational support, psychological support and financial support shows a positive and significant impact. In examining the impact of increased motivation on employees' commitment, the results were also statistically significant and positive. On the basis of the findings it can be concluded that the motivation has a significant and positive impact on employees' commitment so organizations should focus on motivating their employees; however, the method used for motivation can differ from one organization to another.
\end{abstract}

JEL classification: M10, M12, M14, M19, M50, M54, M59

Keywords: motivation, employee commitment, sales professionals, organizational support, financial support, psychological support.

\section{INTRODUCTION}

In this goal oriented world each and every organization wants to pursue its goal and vision, which is only possible with the help of employees working in an organization. It is quite important for employees to have a clear vision of what the organization wants to achieve. To make these employees familiar with the organization's goals, motivation plays a major role. Without motivation an employee would not be disciplined to achieve the organization's goal (Hackman \& Oldham, 1976). Due to fast changing demand of the consumer world, it is very important to deliver products and services in an effective and efficient manner. Sales workforces play a significant role for the effective delivery of such products and services, and for this they are charged with handing over the products and services to the market (Restubog et al., 2006). However, the environment in which the personnel work is very complex, and also due to this it also becomes difficult for the sale person to achieve and improve the industrial sales targets as 
well as market performance (Nikolaou \& Tsaousis, 2002). Hence, it is very important to create motivation in order to improve the productivity by bringing significant changes in sales labour's compensation, performance and goals (Obikeze, 2012).

Motivation is that tool of management which helps develop effective performance of the employees of the company to achieve steady growth and also to face market competition (Sharma \& Patterson, 2000). There are various positive outcomes of motivating a salesperson. It is motivation which helps to create enthusiasm in the salesperson related to his job. Through motivation it is possible to regenerate the interest of the salesperson. Motivation helps salespersons to work in a group so that they will not feel pressure alone, so it helps to maintain a cooperative work environment (Mak \& Sockel, 2001). Motivation provides a sense of inspiration and visualization in their mind so that they could take up their work and do it in a positive way (Burton, 2012). Upon understanding the significance of motivation in influencing effective performance of the organizational workforce, the concerned study aims to evaluate the effect of motivation on the sustenance of commitment of sales professionals. Perennial objectives of the broader aim are:

1. To explore various factors affecting motivation of salespersons.

2. To understand the relationship between motivation and commitment and the former's impact on the latter.

3. To gain insight on increased sales productivity due to increased motivation and commitment.

4. To deduce a model based on the understanding of the concerned issues.

\section{REVIEW OF LITERATURE}

\section{i. Factors affecting motivation of sales professionals: an empirical review}

Motivational factors play a key role to evaluate the change in the behaviour of salespersons and also to verify the performance of the same in an organization. There are two factors which affect the motivation of sales professionals and these are financial and non-financial factors (Meyer et al., 2004).

\section{Financial factors}

Financial factors are conditioned financial rewards that are attractive and motivate behaviour of employees, but are not pleasurable (Eshun \& Duah, 2011). According to the studies of Kubo and Saka (2002), Griffin (2006) and Havaldar and Cavale (2007) the main financial award methods that must be implemented within an organization are: incentive schemes, compensation and cash prize winning contests. Following their definition an empirical investigation has been conducted here, showing the variance in effectiveness of various financial factors for employee motivation.

Kubo and Saka (2002) defined Incentive Scheme as a satisfactory appraisal given to the employees by respective organizations based on their performance, which even increases the chance of earning several salaries as lump sum. Incentive schemes must be organized in the industries so that it would also give a sense of motivation in the employees to work more and hence more. According to the quality of work done by the sales professional, industries must provide incentives and bonuses to them. This would create an excitement in them to work efficiently so that they could earn more (Kubo \& Saka, 2002).

According to Griffin (2006), Compensation, as a financial motivating factor, is the method used within an organization to recruit and retain qualified employees and increase their morale. On the basis of this observation, his study stated that, to build motivation among the sales professional, provision of compensation to them through stocks is an effective way. Company managers purchase stocks at a fixed price. The main idea behind this is to build high performance 
of the company and this practice will increase the stock price and hence consequently the market price value decreases (Griffin, 2006).

However, according to another study conducted by Havaldar and Cavale (2007), cash prize winning contests are the methods employed within an organization to present to employees a token of appreciation for their achievement or for obtaining a desired goal of an organization. According to their study, cash prize winning contests should be organized in companies for sales professionals, so that there would be excitement among salespersons to win such contests. These contests will be close-ended within a company and hence are an excellent way to motivate and evaluate the commitment of sales professional towards their work (Havaldar \& Cavale, 2007).

\section{Non-financial factors}

Non-financial factors are unconditioned rewards that are attractive and motivate behaviour because they are inherently pleasurable. These factors are the integration of a system of reward and recognitions that does not involve giving money directly to the employee (Neagu, 2014). According to the studies of Parker (2003), Deeter-Schmelz and Sojka (2003), Smith, Rupp and William (2003), Armstrong (2008), Marchingston and Wikison (2008) and Wen-Bao Li (2008), the main motivating non-financial award methods that must be utilized within an organization are recognition, organization climate, organizational structure, management and motivational skills, professional development and achievements. Following their definition an empirical investigation has been conducted here, showing the variance in effectiveness of various non-financial factors for employee motivation.

According to Parker (2003), recognition is nothing but an encouragement given to the employees working within an organization. The organization creates motivation through non-financial recognition schemes like praise, voucher and nomination based schemes. It is an important non-financial method that must be adopted within an organization. Recognition is a form of gratitude given by an organization to its employees. The motive behind this is to create the encouragement among the employees working in a team as well as other employees. It is a cheap way to increase the performance of an organization and it is possible by employing verbal, such as rewards, praise, and non-verbal recognition methods like expressions, gestures, etc. (Parker, 2003).

But contrary to this, the study of Thomas B. Wilson, titled "Innovative reward systems for the changing work place" suggests that recognition cannot improve the performance of an organization alone but also helps to create a sense of motivation in an employee working in a particular organization (Wilson, 2003).

According to the study of Deeter-Schmelz and Sojka (2003), another non-financial factor that affects the motivation of sales professional is the organization climate. According to the study organization climate is the way in which different employees within an organization treat each other. Some of the strategies of developing organizational climate involve establishing a friendly attitude among employees, irrespective of their position, thereby motivating their performance and work done by them in the organization. However there are other types of employees who demotivate the performance of employees by making vague comments about their performance, which totally distracts a person from work and thus has a negative impact on the overall performance of an organization (Deeter-Schmelz \& Sojka, 2003).

The structure of an organization also affects the working way of an employee according to the research of Smith, Rupp and William (2003). It is the method that must be developed in an organization to evaluate the nature of work, performance and employee attitude in an organization. It all depends upon the organizational structure that evaluates the performance of the industry. Sometimes it is the nature of work or the type of work that influences the employee to do it. An employee's positive attitude motivates him to do the work and provides him with positive energy; if an employee finds the work exciting and challenging then it would also motivate him (Smith \& Rupp, 2003). 
Based on the definition given by Armstrong (2008), motivational skills are those which must be employed within an organization in order to energize people to do what comes from their inside. Basically management skills must be utilized within an organization to build the motivational skills of the company, and these skills can be used by the sales professionals to improve the performance of the company (Armstrong, 2008).

According to the study of Marchingston and Wikison (2008) regarding the importance of adopting non-financial factors to motivate employees in an organization, professional development and achievement plays an important role in the development of motivational skills of the professionals working in an organization because it is this workforce who provides skills to other employees in turn, consequently impacting the work performance of employees.

It is not necessary for managers to motivate employees or sales professional but it is required that they should provide opportunities to employees so that they could improve their performance (Marchington \& Wilkinson, 2008).

A similar study was conducted by Wen-Bao Li (2008), finding that professional development and professional achievements are other factors that motivate sales professional in an organization. It is the professional people who motivate employees in an organization. A professional person provides employees with skills which will help them to make an impact on their work in the organization to attain a good position in an organization by achieving success (Lin, 2008).

\section{ii. Outcomes of motivation}

Motivation helps to improve the performance of a business organization. Two main outcomes of motivation are: organizational commitment and increased productivity (Sujan et al., 1988).

\section{Organizational commitment}

Commitment is an art that reflects the loyalty of an employee towards an organization. This commitment comes only if the employees of the organization are motivated. Employee motivation plays a crucial role to build employee commitment toward work in a particular organization (Dagne et al., 2015). Commitment in an organization is determined through three factors: personal factors, organizational factors and non-organizational factors. Personal factors include age, pay, internal, external attributes, and others. Organizational factors include job design and supervisor's style of leadership, so motivation can be built by focusing on these factors. Non-organizational factors include various business alternatives (Lai et al., 2012). There are three features by which employees are motivated to work in an organization and these features are visibility acts, the extent to which the outcomes are derived and voluntary action of an employee in an organization (Ellis, 2000). There are three components that define the motivation and commitment of an employee in an organization and these are: willingness of an employee to represent himself from the organization side, strong employee desire to serve in an organization and to identify with the organization values etc. There is a direct relation between motivation and commitment. The greater the motivation, the greater the commitment of an employee to work in an organization (Sange \& Srivastava, 2012).

\section{Increased productivity}

Motivation plays an important role to increase the productivity of an organization (Murphy, 2004). Whatever may be the size of an organization, either big or small, the common aim is to achieve success in today's fast growing world. The success of an organization is possible only if the employees are highly motivated. This success is measured by the degree of productivity. So to succeed in a competitive market it is important to formulate the goals and objectives in an organization and to formulate these goals, motivation regarding the vision and goal should be built 
among organization employees; otherwise this dream would be difficult to turn into reality (Little, 2012). Companies cannot ignore the factors which contribute to arousing the most important factor that is motivation. The activities which are involved in the productivity of an organization comprise capital, entrepreneur, land and last but not the least labour. The entrepreneur and labour are the most important factors among which there is a great need to motivate employees so as to increase productivity (William, 2010). The more the employees of a company are motivated towards achieving the vision of the enterprise, the higher the overall productivity.

\section{RESEARCH METHODOLOGY}

Research methodology will enable the researcher to study the effect of motivation on sales professionals and to sustain their commitment in an organization, through an analysis of firsthand data. But before discussing the various methods applied and their implications in the study, the conceptual framework highlighting the major concepts of exploration and understanding related to the issue at hand has been presented:

\section{Figure 1}

Conceptual framework based on the insights gained from the review of literature

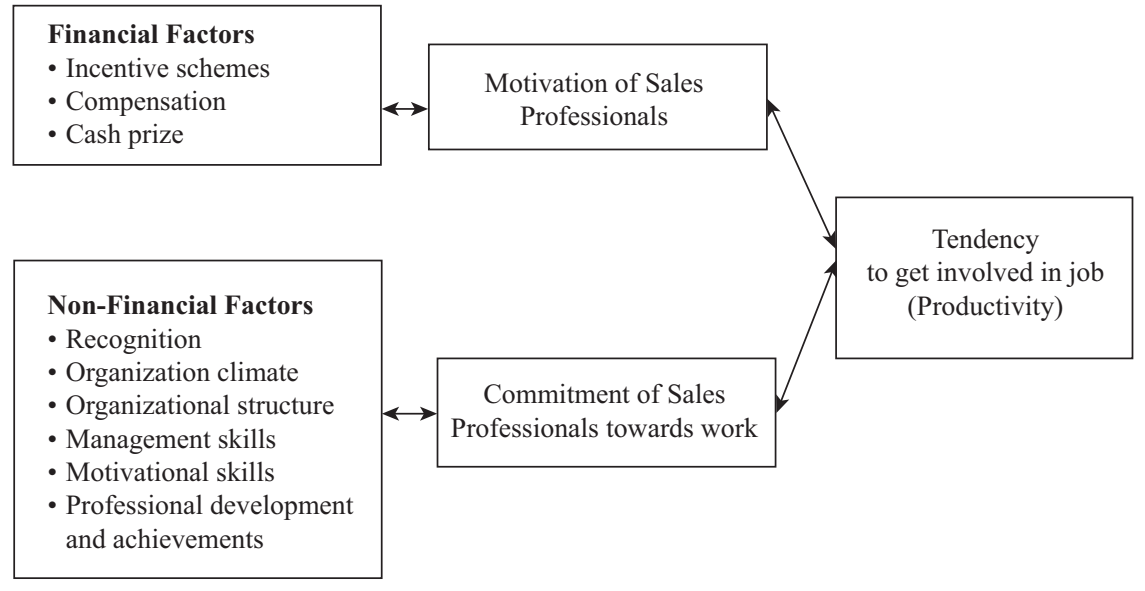

From this figure it can be evaluated that motivation has a direct impact on a sales professional's way of working which will in turn sustain commitment and thereby the tendency to work in an organization or get involved in the job also changes. The more the sales professionals and employees are motivated, the greater their commitment, and hence, the tendency to get involved in the job will be, meaning increased productivity.

Motivational Impact on Sales: It is the motivation of sales professionals that directly impacts the overall sale of the products in an industry. It is very important that the employees serving in industries should be highly motivated with a clear focus and vision to improve the economic growth of the country. It can either have a positive or negative impact on an industry's performance. Various factors should be taken into consideration within an industry to motivate sales professionals. These factors can be financial or non-financial.

Commitment of Sales Professionals: As stated earlier commitment is nothing but a promise of an employee towards his organization. Commitment is important because without commitment success is not possible. Hence it is very crucial that employees must be committed towards their work. Their commitment depends upon the nature of the work given to them, so it must be made sure that work is in line with the interest of an employee. It is the desire of an employee that makes the employee loyal towards his work. Commitment and motivation terms are linked to one another. 
Tendency to get involved in the job: Both commitment and motivation are important to evaluate the overall performance of an organization. If the employees or sales professional are highly motivated towards their job and are highly committed towards the task they are assigned then this would surely increase the productivity, which would further lead to an economic development of a company. An employee's tendency to get involved in the job depends upon financial and non-financial factors. Financial factors (incentive schemes, compensation, cash prize, etc.) are conditioned financial reward methods that are attractive and motivate behaviour of employees, but are not pleasurable. Non-financial factors are unconditioned rewards that are attractive and motivate behaviour because they are inherently pleasurable. Non-financial methods that must be utilized within an organization are recognition, organization climate, organizational structure, management and motivational skills, professional development and achievements.

Upon identifying the key elements within the conceptual framework, the following null hypotheses were proposed for further examination and interpretation:

H1: Employee's engagement strategies within an organization positively influences employee motivation;

H2: Factors affecting employee's motivation and commitment are unidimensional;

H3: Increased employee motivation and commitment has an effective impact on skill enhancement and organizational performance.

3.1. Research Design: Exploratory design is used to gain insight on the effect of motivation and also its impact on the performance of sales professionals in an organization as per the literature. Descriptive design has been used in order to collect the data from the demographic profile and personal background of the respondents (Vance, 2004). Furthermore, the explanatory design has enabled the researcher to ascertain the triangular relationship between motivation, organizational commitment and increased productivity of sales professionals.

3.2. Sampling Plan: In this study the respondents were the sales staff of three multinational companies of a metro city of India. About 200 sales professionals were chosen on whom a survey was conducted using a close-ended and structured questionnaire. The survey was conducted personally by the researcher, distributing the questionnaires to the respondents randomly, following the probability random sampling plan. An appropriate prior permission was obtained from the Human Resource (HR) department and the Office of the Country Manager of the companies upon explaining to them the aim and purpose of the study. Besides, informed consent forms were also collected from the respondents before initiating the survey.

3.3. Data Analysis Procedure: Data gathered from the survey through a quantitative approach has been analysed deductively, by coding the views numerically using MS Excel. Under the descriptive analysis, the frequency technique was applied to get an overview of the data and a brief profile of the respondents. A linear regression analysis was conducted to measure the level of motivation provided by the organization through various engagement strategies. Following the identification of the engagement strategies and employee motivation, a factor analysis was carried out to identify the major factors influencing the motivation and consequent commitment of the employees towards the organization. Lastly, a linear regression analysis was again performed to examine the casual relationship between these factors and the outcomes of increased motivation of employees. Later, statistical results were obtained by transferring the data into SPSS software (v21.0), which data was then interpreted. The representation and analysis of the results are presented in tables, graphs and figures under the findings section. 


\section{FINDINGS}

The current research is aimed at examining the impact of motivation on the commitment of sales professionals. For the analysis purpose data has been collected among 100 sales professionals in various organizations. Both descriptive and inferential analysis has been conducted to obtain the results.

\subsection{Descriptive analysis}

A descriptive analysis has been conducted to get an overview of the data and a brief profile of the respondents. Results from the demographic profile show that $41 \%$ of the respondents were in the age group of 31-40, which was followed by $35 \%$ in the age group of $21-30$. The proportion of the respondents who were more than 40 years of age was just $24 \%$, which indicates that most of the respondents were young.

\section{Figure 2}

Age of the respondents

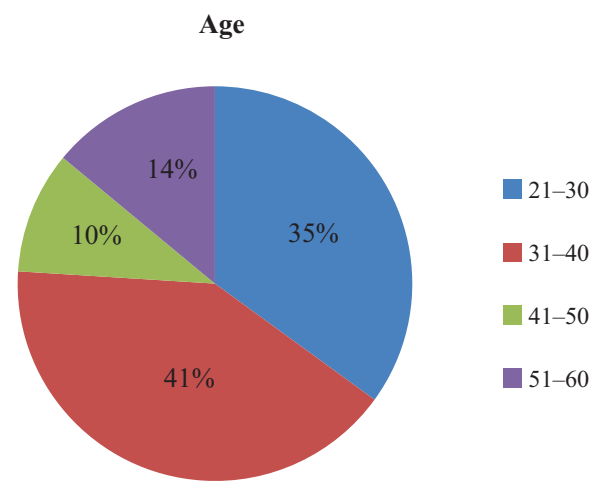

Similarly the sector-wise distribution of the respondents shows that $55 \%$ of the respondents were engaged in the public sector whereas the remaining $45 \%$ were in the private sector. In terms of experience the results show that most (47\%) respondents have 1 to 5 years of experience.

\section{Figure 3}

Sector and total work experience of the respondents
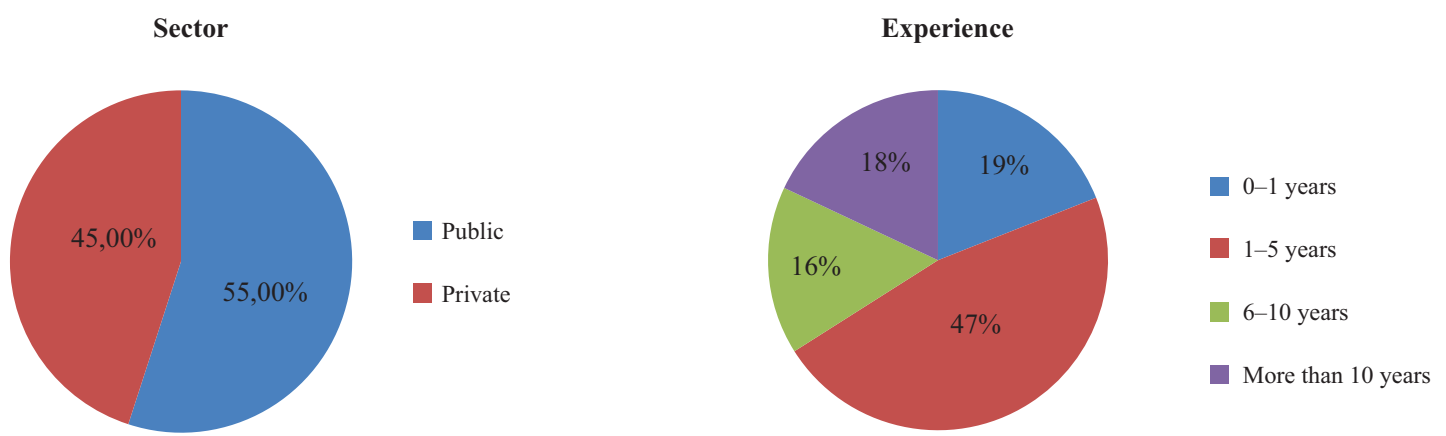

On the other hand, only $18 \%$ of the respondents had worked for more than 10 years in the current organization and $19 \%$ of the respondent had less than one year of experience.

Similarly, to know the current scenario of employee's motivation and employee commitment towards the organization, the respondents were asked to respond on various aspects of motivation in their organization. As shown in the figure below the majority of respondents think that commitment of employees towards the organization depends on employee motivation. 
Figure 4

General information about motivation and employee engagement in the organization

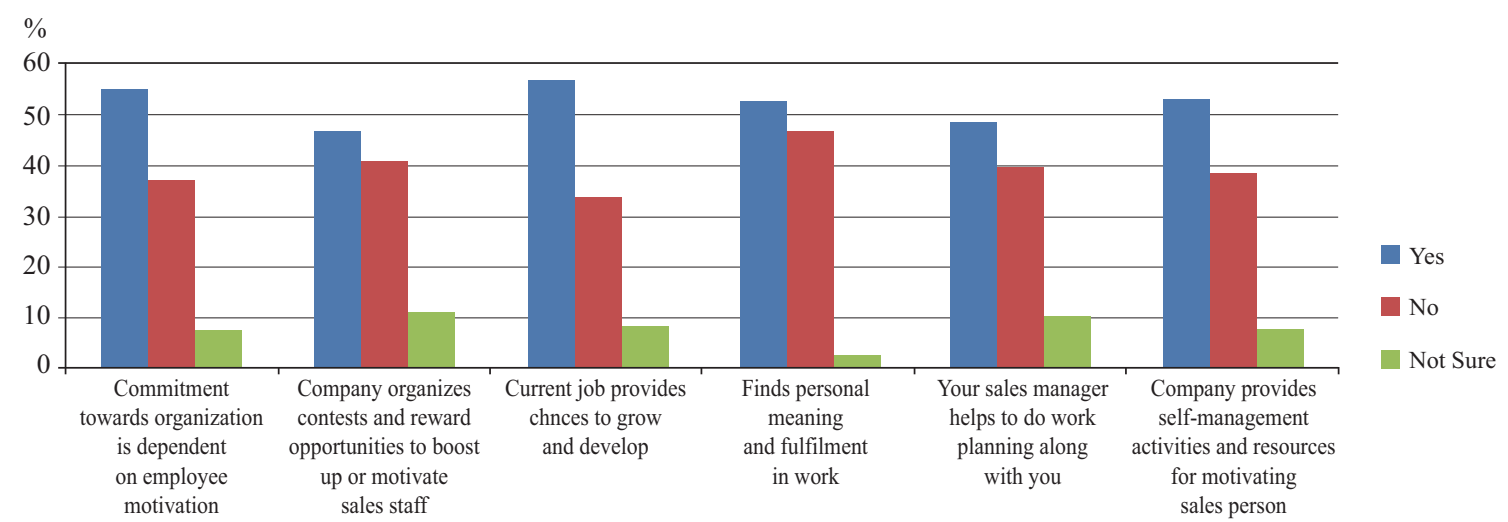

When asked whether their organization offers reward and opportunities for their employees to motivate sales staff, only $47 \%$ said "yes", $41 \%$ responded "no" and the rest of them were not sure. Similarly $57 \%$ of the respondents think that their current job provide them with a chance to develop and 53\% of the respondents agree that they are able to find personal meaning in their current work. In terms of the role played by the management in motivating employees, $49 \%$ of the respondents get help from their managers in sales planning and for $53 \%$ of the respondents their company provides self-management activities to motive the employees in the organization.

\subsection{Inferential analysis}

The inferential analysis has been conducted with the help of correlation and multiple regression analysis with an aim to examine the impact of motivation to sustain commitment of sales professionals.

\section{Employee engagement within organization}

To measure the level of motivation provided by an organization to improve employee commitment, a multiple regression analysis was conducted. Employee engagement in the organization was taken as the dependent variables and the various aspects of employee motivation were taken as the independent variables. Prior to conducting the regression analysis the Pearson correlation analysis was conducted and the results showed that most of the variables are correlated significantly at $5 \%$. 
Figure 5

Regression results for employee engagement in the organization

\begin{tabular}{|c|c|c|c|c|c|c|}
\hline & & & oefficients & & & \\
\hline & Model & Unstanda & Coefficients & $\begin{array}{l}\text { Standardized } \\
\text { Coefficients }\end{array}$ & $\mathrm{t}$ & Sig. \\
\hline & & B & Std. Error & Beta & & \\
\hline & (Constant) & -.180 & .049 & & -3.649 & .000 \\
\hline & $\begin{array}{l}\text { A positive attitude toward } \\
\text { the organization }\end{array}$ & .061 & .029 & .061 & 2.137 & .035 \\
\hline & $\begin{array}{l}\text { Willingness to behave } \\
\text { altruistically }\end{array}$ & .122 & .030 & .123 & 3.985 & .000 \\
\hline & $\begin{array}{l}\text { Going beyond the } \\
\text { requirements of the job }\end{array}$ & -.010 & .027 & -.011 & -.382 & .703 \\
\hline 1 & $\begin{array}{l}\text { I am proud to work for my } \\
\text { organization }\end{array}$ & .133 & .036 & .129 & 3.691 & .000 \\
\hline & Great place to work & .399 & .049 & .401 & 8.173 & .000 \\
\hline & $\begin{array}{l}\text { To go "above and beyond" } \\
\text { expectations }\end{array}$ & .048 & .034 & .048 & 1.406 & .163 \\
\hline & $\begin{array}{l}\text { Put in a great deal of effort } \\
\text { beyond normal expectations }\end{array}$ & .111 & .032 & .116 & 3.436 & .001 \\
\hline & $\begin{array}{l}\text { Organization's overall } \\
\text { goals, objectives and } \\
\text { direction }\end{array}$ & .043 & .027 & .045 & 1.587 & .116 \\
\hline & Inspiration & .148 & .034 & .152 & 4.346 & .000 \\
\hline $\begin{array}{ll}\text { a. } & \\
A \\
F \\
D\end{array}$ & $\begin{array}{l}\text { endent Variable: Employee engagem } \\
\text { usted R square: } 0.90 \\
\text { tistic: } 0.000 \\
\text { in Watson: } 2.002\end{array}$ & vithin orgar & & & & \\
\hline
\end{tabular}

Results from the regression analysis show that $90 \%$ of the variation in the dependent variable is due to a change in the independent variable as the value of adjusted $\mathrm{R}$ square is 0.90 . Since the F statistic is significant the cumulative effect is also significant and the result from Durbin-Watson test rejects the possibility of autocorrelation in the variables.

Results from the regression coefficient show that among nine independent variables included in the model eight of the variables, that is "Willingness to behave altruistically", "I am proud to work for my organization", "Great place to work", "Put in a great deal of effort beyond normal expectations", "Organization's overall goals, objectives and direction", "Inspiration", "To go 'above and beyond' expectations" and "A positive attitude toward the organization", show positive and significant impact on the dependent variables whereas the results for the remaining three variables were not statistically significant.

The coefficient of great place to work (0.399) can be interpreted as such that, with a one unit increase in this feeling of an employee, the engagement of the employee in the organization increases by 0.399 unit, holding all other things constant. All other regression coefficients can also be interpreted in a similar way. The coefficient of inspiration (0.148) can be interpreted as such that, with a one unit increase in the inspiration in an employee, the engagement of an employee in the organization increases by 0.148 units, holding all other things constant. Similarly the coefficient of an employee feeling proud to work for the organization $(0.133)$ can be interpreted as such that a one unit increase in the employee's feeling to be proud increases his engagement in 
the organization by 0.133 unit, holding all other things constant. The coefficient of willingness of employees to behave altruistically $(0.122)$ can be interpreted as such that, with a one unit increase in the willingness of an employee, the engagement of the employee in the organization increases by 0.122 unit, holding all other things constant.

A study conducted by Markos and Sridevi (2010) exhibited an employee's engagement in an organization as being affected by many factors which involve both emotional and rational factors, that is employees' willingness and ability to help their company succeed, largely by making an effort on a sustainable basis relating to work, and also revealed that the overall work experience affects an organization's performance. A similar study was conducted by Vance (2004), according to whom organizations employ several engagement strategies that have a significant impact on employees as well as the organization. Through the study it was inferred that the more the employees are committed towards their work, the greater the organization's productivity will be (Vance, 2004).

As per the above results, the null hypothesis "Employee's engagement within an organization is positively affected by employee's motivation" has been proved and justified.

\section{Factors affecting motivation and commitment of employees}

Three main factors were identified on the basis of literature reviews which influence the motivation and commitment of employees towards the organization. Three main factors include organizational factor, psychological factor and financial support. The impact of each factor for the current study has been presented in the following table.

The first factor is the organizational culture and the results show that the adjusted $\mathrm{R}$ square is 0.89 , which means that $89 \%$ of the variation in the dependent variable is due to the independent variables and the cumulative effect is also significant. Similarly, the results show that training, performance appraisal, skill development and reward have a positive and significant impact in the organizational culture.

Figure 6

Regression results for factors affecting the motivation and organizational commitment

\begin{tabular}{|c|c|c|c|c|}
\hline \multicolumn{5}{|c|}{ Factors affecting motivation and commitment } \\
\hline \multicolumn{4}{|c|}{ Organizational Support } & \multirow[b]{3}{*}{ Significance } \\
\hline \multicolumn{4}{|c|}{ Adjusted R square: 0.89 F statistic: 0.000 Durbin Watson: 1.824} & \\
\hline & B coefficient & Standard error & $\mathrm{T}$ - value & \\
\hline Training & 0.341 & 0.071 & 4.794 & 0.000 \\
\hline Performance Appraisal & 0.229 & 0.062 & 3.687 & 0.000 \\
\hline Skill Development & 0.211 & 0.082 & 2.573 & 0.012 \\
\hline Reward & 0.210 & 0.084 & 2.497 & 0.014 \\
\hline Future Relationship & 0.051 & 0.033 & 1.525 & 0.131 \\
\hline \multicolumn{5}{|c|}{$\begin{array}{l}\text { Psychological Support } \\
\text { Adjusted R square: } 0.83 \text { F statistic: } 0.000 \text { Durbin Watson: } 1.52\end{array}$} \\
\hline Availability of resources & 0.347 & 0.077 & 4.521 & 0.000 \\
\hline Staff participation & 0.204 & 0.066 & 3.076 & 0.003 \\
\hline Interaction among staff & 0.314 & 0.076 & 4.151 & 0.000 \\
\hline $\begin{array}{l}\text { Safety measures, risk } \\
\text { assessment, norms }\end{array}$ & 0.173 & 0.059 & 2.906 & 0.005 \\
\hline
\end{tabular}


Financial Support

Adjusted R square: 0.89 F statistic: 0.000 Durbin Watson: 1.753

\begin{tabular}{lcccc} 
Salary increment & 0.430 & 0.050 & 8.540 & 0.000 \\
\hline $\begin{array}{l}\text { Bonuses and wages } \\
\text { provided in company }\end{array}$ & 0.298 & 0.047 & 6.283 & 0.000 \\
\hline Profit sharing practices & 0.294 & 0.047 & 6.219 & 0.000
\end{tabular}

The second factor included in the analysis is the psychological factor and results show that the independent variables included in the regression model are able to explain $83 \%$ of the variation in the dependent variable and the cumulative effect of independent variables in the dependent variable is also significant as indicated by the F statistic. Similarly, available resources, staff participation, interaction among staff and various safety measures show a significant and positive impact on the psychology of employees so an organization should focus on these factors to motive its employees.

The third and last factor is the financial factor and the results are also statistically significant, as the adjusted $\mathrm{R}$ square is 0.89 and $\mathrm{F}$ statistic is also significant at $1 \%$. The regression coefficients of independent variables are also positive and statistically significant.

However, according to the Dobre's (2013) study, employees within an organization can also be motivated through proper leadership, as leadership is all about getting things done the right way. To achieve an organization's goals, the leader should gain the trust of employees. Nevertheless, in order to make employees trust leaders in the organization, the employees should be motivated. Also according to the study proposed by Danish and Munir (2012), a major factor that impacts motivation and commitment of employees is the financial support given by an organization to its employees and it was noted that it has a significant and positive impact on employees' performance. Also, an increase in motivation from the organization shows a positive and significant impact on commitment of the employees to the organization (Danish \& Munir, 2012).

Hence, as per the above results, hypothesis "Factors affecting employee's motivation and commitment has a positive influence on an organization's performance" has been proved and justified.

\section{Outcome of increased motivation and commitment}

The impact of increased motivation on commitment of employees towards the organization has been examined and the results are shown below. To assess the impact, a separate regression analysis was conducted by taking increased motivation as the independent variable and the possible outcome as the dependent variable so that the impact of increased motivation can be realized. 
Figure 7

Regression results for outcomes of increased motivation and commitment

\begin{tabular}{|c|c|c|c|c|c|c|c|}
\hline \multicolumn{8}{|c|}{ Outcomes of increased motivation and commitment } \\
\hline & $\begin{array}{l}\text { Adjusted R } \\
\text { square }\end{array}$ & F statistic & D-W & B coefficient & $\begin{array}{l}\text { Standard } \\
\text { error }\end{array}$ & T-value & Significance \\
\hline $\begin{array}{l}\text { To face } \\
\text { competitive } \\
\text { market }\end{array}$ & 0.673 & 0.000 & 1.370 & 0.891 & 0.062 & 14.313 & 0.000 \\
\hline $\begin{array}{l}\text { Build enthusiasm } \\
\text { in sales staff }\end{array}$ & 0.721 & 0.000 & 1.515 & 0.834 & 0.052 & 16.025 & 0.000 \\
\hline $\begin{array}{l}\text { Regenerate the } \\
\text { sales staff interest } \\
\text { in work }\end{array}$ & 0.517 & 0.000 & 2.301 & 0.736 & 0.071 & 10.340 & 0.000 \\
\hline $\begin{array}{l}\text { Helps to maintain } \\
\text { cooperative work } \\
\text { environment }\end{array}$ & 0.469 & 0.000 & 1.752 & 0.723 & 0.077 & 9.412 & 0.000 \\
\hline $\begin{array}{l}\text { Sense of building } \\
\text { positive attitude in } \\
\text { staff }\end{array}$ & 0.689 & 0.003 & 2.576 & 0.836 & 0.056 & 14.849 & 0.000 \\
\hline
\end{tabular}

As the results show increased motivation has a positive and significant impact on employees' commitment as all the independent variables show a significant impact. The regression coefficient of enthusiasm (0.721) can be interpreted as such that, with a one unit increase in the motivation, the enthusiasm of the sales staff increases by 0.721 unit, holding other things constant. All other coefficients can also be interpreted in a similar way. The regression coefficient of sense of building positive attitude in staff $(0.689)$ can be interpreted as such that a one unit increase in the motivation, the attitude of sales staff increases by 0.689 unit, holding other things constant. Similarly, the regression coefficient of facing competitive market (0.673) can be interpreted as such that, with a one unit increase in the motivation, the competition faced by sales staff increases by 0.673 unit, holding other things constant.

Similar results were proven by Muogbo (2013), according to whom motivation has a positive impact on an organization's performance. The study inferred that creating motivation and winning the hearts of employees help an organization to regenerate the sales in meeting customer demand and hence making profit (Muogbo, 2013). A similar study was proposed by Nguyen et al. (2014), who recommend commitment-based organizations to continue and reinforce organizational support for their staff.

As per the above results, hypothesis "Employee motivation positively impacts employees' commitment towards the organization" has been accepted and justified.

\section{DISCUSSION AND CONCLUSION}

In the competitive world the main aim of every organization is to achieve its organizational goals and the engagement and commitment of the employees is an important factor in achieving the goal and there should be enough motivation for the employees. In this light, the current research is aimed at examining the impact of motivation to sustain commitment of sales professionals. For data analysis primary data was collected among 100 sales professional and both the descriptive and inferential analysis was conducted to obtain the results. Findings from the analysis show that among various factors which were included to measure the motivation for employees in the organization, most of them show significant results. Similarly all three major 
factors (organizational support, psychological support and financial support) have a significant and positive impact on motivation and commitment of the employees. Also, an increase in motivation from the organization shows a positive and significant impact on commitment of the employees to the organization.

\section{ACKNOWLEDGEMENT}

I take this opportunity to express my deep sense of gratitude and profound thanks to Mr. Krzysztof Cybulski (Ph.D.), Faculty of Management, University of Warsaw, Poland for his kind guidance and support. I am also grateful to University of Warsaw and Erasmus Mundus Action 2 IBIES Programme for giving me the opportunity to pursue my Ph.D. I would also like to thank Mr. Rajesh Pahurkar (Assistant Professor, Department of Management Sciences - PUMBA, SavitribaiPhule Pune University - Formerly University of Pune) for his timely help and support.

\section{References}

Armstrong, M. (2008) How To Be an Even Better Manager, London. Available at: http://ebooks.rahnuma.org/ management/Safety and management ebooks/Management/Armstrong's Handbook of Management and Leadership.pdf.

Burton, K. (2012) A Study of Motivation : How to Get Your Employees Moving. Indiana University. Available at: $\mathrm{https} / / /$ spea.indiana.edu/doc/undergraduate/ugrd_thesis2012_mgmt_burton.pdf.

Dagne, T., Beyene, W. \& Berhanu, N. (2015) "Motivation and Factors Affecting It among Health Professionals in the Public Hospitals, Central Ethiopia, Ethiopian Journal of Health Sciences, 25(3), pp. 231-242. Available at: http://www.ncbi.nlm.nih.gov/pmc/articles/PMC4650878/.

Danish, R.Q. \& Munir, Y. (2012) "The Impact of Motivation on Employee's Commitment: Evidence from Public and Private Sector of Pakistan", World Review of Business Research, 2(1), pp. 109-118.

Deeter-Schmelz, D.R. \& Sojka, J.Z. (2003) "Developing Effective Salespeople: Exploring The Link Between Emotional Intelligence And Sales Performance", The International Journal of Organizational Analysis, 11(3), pp. 211-220. Available at: http://dx.doi.org/10.1108/eb028972.

Dobre, O.I. (2013) "Employee motivation and organizational performance", Review of Applied Socio- Economic Research, 5(1), p. 53.

Ellis, N. (2000) "Developing graduate sales professionals through co-operative education and work placements: a relationship marketing approach", Journal of European Industrial Training, 24(1), pp. 34-42. Available at: http://dx.doi.org/10.1108/03090590010308246.

Eshun, C. \& Duah, F.K. (2011) Rewarda as a Motivation Tool for Employee Performance.

Griffin, R.W. (2006) Fundamentals of Management, 7th Edition, Texas A\&M University.

Hackman, J.R. \& Oldham, G.R. (1976) "Motivation through the design of work: test of a theory", Organizational Behavior and Human Performance, 16(2), pp. 250-279. Available at: http://www.sciencedirect.com/science/ article/pii/0030507376900167.

Havaldar, K.K. \& Cavale, V. (2007) Sales \& Distribution Management, Tata McGraw Hill, p.8. Available at: http:// www1.ximb.ac.in/users/off/dean/dodox4co.nsf/27e84f44a7052f4ce52569fe00080a03/5510966d19cb86b765 257b4100348d9e/\$file/sdm.pdf.

Kubo, I. \& Saka, A. (2002) "An inquiry into the motivations of knowledge workers in the Japanese financial industry", Journal of Knowledge Management, 6(3), pp. 262-271. Available at: http://dx.doi. org/10.1108/13673270210434368.

Lai, C., Teachers, P. \& Kong, H. (2012) "Motivation and Commitment : at a Training Institute in Hong Kong", Teacher Education Quarterly, (6), pp.45-61.

Lin, W. (2008) "Factors enhancing the intentions of employees toward customer-oriented behaviors", International Journal of Commerce and Management, 18(3), pp. 267-288. Available at: http://dx.doi. org/10.1108/10569210810907173.

Little, B. (2012) "Identifying key trends in sales - from a training perspective", Industrial and Commercial Training, 44(2), pp. 103-108. Available at: http://dx.doi.org/10.1108/00197851211202948.

Mak, B.L. \& Sockel, H. (2001) "A confirmatory factor analysis of IS employee motivation and retention", Information \& Management, 38(5), pp. 265-276. Available at: http://www.sciencedirect.com/science/article/ pii/S0378720600000550. 
Marchington, M. \& Wilkinson, A. (2008) Human resource management at work: people manage ment and development. Springer Company, Inc., London.

Markos, S. \& Sridevi, S. (2010) “Employee Engagement: The Key to Improving Performance”, International Journal of Business and Management, 5(12), pp. 89-96.

Meyer, J.P. et al. (2004) «Employee Commitment and Motivation : A Conceptual Analysis and Integrative Model», Journal of Applied Psychology, 89(6), pp. 991-1007.

Muogbo, B.U. (2013) "The Impact of Employee Motivation On Organisational Performance (A Study Of Some Selected Firms In Anambra State Nigeria)", The International Journal Of Engineering And Science, pp. 2319-1813.

Murphy, W.H. (2004) "In pursuit of short-term goals: anticipating the unintended consequences of using special incentives to motivate the sales force", Journal of Business Research, 57(11), pp. 1265-1275. Available at: http://www.sciencedirect.com/science/article/pii/S0148296302004472.

Neagu, C. (2014) "Non-Financial Motivation of Staff - Challenges and Solutions", Revista Română de Statistică Supliment, (4), pp. 74-77.

Nguyen, T.N., Mai, K.N. \& Nguyen, P. V. (2014) "Factors Affecting Employees' Organizational Commitment A Study of Banking Staff in Ho Chi Minh City, Vietnam”, Journal of Advanced Management Science, 2(1), pp. 7-11. Available at: http://www.joams.com/index.php? $\mathrm{m}=$ content\&c=index\&a=show\&catid=36\&id=106.

Nikolaou, I. \& Tsaousis, I. (2002) "Emotional Intelligence In The Workplace: Exploring Its Effects On Occupational Stress And Organizational Commitment”, The International Journal of Organizational Analysis, 10(4), pp. 327-342. Available at: http://dx.doi.org/10.1108/eb028956.

Obikeze, C.O. (2012), Effects of Motivation on Sales Force Performance in Guinness Nigeria Plc and MTN in South-East, Nigeria. University of Nigeria. Available at: http://www.unn.edu.ng/publications/files/images/ OBIKEZE, CHINEDUM OKEY.pdf.

Parker, G.M. (2003) “Cross-Functional Teams”, The Jossey-Bass Business \& Management Series, pp. 1-34.

Restubog, S.L.D., Bordia, P. \& Tang, R.L. (2006) "Effects of psychological contract breach on performance of IT employees: The mediating role of affective commitment", Journal of Occupational and Organizational Psychology, 79(2), pp. 299-306. Available at: http://dx.doi.org/10.1348/096317905X53183.

Sange, R. \& Srivastava, R.K. (2012) "Employee Engagement and Mentoring: An Empirical Study of Sales Professionals", Synergy, 10(1), pp. 37-50.

Sharma, N. \& Patterson, P.G. (2000) "Switching costs, alternative attractiveness and experience as moderators of relationship commitment in professional, consumer services", International Journal of Service Industry Management, 11(5), pp. 470-490. Available at: http://dx.doi.org/10.1108/09564230010360182.

Smith, A.D. \& Rupp, W.T. (2003) "An examination of emerging strategy and sales performance: motivation, chaotic change and organizational structure", Marketing Intelligence \& Planning, 21(3), pp. 156-167. Available at: http://dx.doi.org/10.1108/02634500310474.

Sujan, H., Weitz, B.A. \& Sujan, M. (1988) “Increasing Sales Productivity By Getting Salesperson To Work Smarter”, Journal of Personal Selling \& Sales Management, (August), pp. 9-19. Available at: http://bear.warrington. ufl.edu/weitz/papers/Increasing_Sales.pdf.

Vance, R.J. (2004) Employee Engagement and Commitment, USA. Available at: file://C:/Users/hp/Desktop/1006Em ployeeEngagementOnlineReport.pdf.

William, A.N. (2010) “Employee Motivation And Performance”, Business Management, (December), pp. 1-81. Available at: http://www.theseus.fi/bitstream/handle/10024/22787/akah_william.pdf.

Wilson, T.B. (2003) Innovative reward systems for the changing work place, New York. 


\section{APPENDIX: 1 - QUANTITATIVE QUESTIONNAIRE}

The following questions are addressed to define the effects of motivation to sustain commitment of sales professionals. The goal of the study is to gain insight on increased sales productivity due to increased motivation and commitment. With regard to the study following are the survey questions distributed among various level employees of the Sales Department.

Your participation is deemed to be voluntary and your identity, as well as your answers to the questions, will remain confidential.

Thank you.

\section{Respondent's Name:}

\section{Section A: Demographic profile and general background of the respondents}

1. What is your age?
$21-30$
$31-40$
$41-50$
$51-60$

2. Which sector does your enterprise belong to?

Public

Private

3. How long have you been working with your current enterprise?
0-1 year
$1-5$ years
6-10 years
More than 10 years

4. What is your position in the enterprise?

Manager (Sales Department)

Middle Management Executive

Junior Management Executive

Team Leader

Others

\section{Section B: Respondent's perception about motivation and commitment}

5. On your professional front, do you think commitment towards organization is dependent on employee motivation?

Yes $\square \quad$ No

Can't say

6. Does your company organize contests and reward opportunities to boost up or motivate sales staff?

Yes $\square \quad$ No

Not sure

7. Does your current job provide chances to grow and develop?

Yes

$\square \quad$ No

Not sure

8. Do you find personal meaning and fulfilment in work?

Yes

No

Not sure 
9. Does your sales manager help to do work planning along with you?

Yes

No

Not sure

10. Does your company provide any self-management activities and resources for motivating salespersons?

Yes

No

Not sure

11. Employee engagement within organization (Measurement of level of motivation)

The following questions are based on a 5 point scale (strongly agree), where 5 denotes most important and 1 denotes strongly disagree, with 3 being neutral. All questions are divided into 3 sub-sections delving into various sectors, bringing out the factors that have an impact on small and medium enterprises.

\begin{tabular}{|c|c|c|c|c|c|}
\hline & 5 & 4 & 3 & 2 & 1 \\
\hline A positive attitude toward, and pride in, the organization & $\square$ & $\square$ & $\square$ & $\square$ & $\square$ \\
\hline Willingness to behave altruistically and be a good team player & $\square$ & $\square$ & $\square$ & $\square$ & $\square$ \\
\hline $\begin{array}{l}\text { An understanding of the bigger picture and willingness to go beyond } \\
\text { the requirements of the job }\end{array}$ & $\square$ & $\square$ & $\square$ & $\square$ & $\square$ \\
\hline I am proud to work for my organization & $\square$ & $\square$ & $\square$ & $\square$ & $\square$ \\
\hline I would recommend my organization as a great place to work & $\square$ & $\square$ & $\square$ & $\square$ & $\square$ \\
\hline $\begin{array}{l}\text { I am motivated to go "above and beyond" what is expected } \\
\text { of me in my job }\end{array}$ & $\square$ & $\square$ & $\square$ & $\square$ & $\square$ \\
\hline $\begin{array}{l}\text { I am willing to put in a great deal of effort beyond what is normally } \\
\text { expected to help my organization succeed }\end{array}$ & $\square$ & $\square$ & $\square$ & $\square$ & $\square$ \\
\hline $\begin{array}{l}\text { I understand how my role in my organization is related } \\
\text { to my organization's overall goals, objectives and direction }\end{array}$ & $\square$ & $\square$ & $\square$ & $\square$ & $\square$ \\
\hline My organization inspires me to do my best work & $\square$ & $\square$ & $\square$ & $\square$ & $\square$ \\
\hline
\end{tabular}

\section{Section C: Factors increasing motivation and commitment}

12. The following questions are based on a 5 point scale (strongly agree), where 5 denotes most important and 1 denotes strongly disagree, with 3 being neutral. All questions are divided into 3 sub-sections delving into various sectors, bringing out the factors that have an impact on small and medium enterprises.

\begin{tabular}{|c|c|c|c|c|c|}
\hline Factors & 5 & 4 & 3 & 2 & 1 \\
\hline \multicolumn{6}{|c|}{ Organization Support } \\
\hline Training provision within the organization & $\square$ & $\square$ & $\square$ & $\square$ & $\square$ \\
\hline Performance appraisal programmes in the organization & $\square$ & $\square$ & $\square$ & $\square$ & $\square$ \\
\hline Skill development programmes & $\square$ & $\square$ & $\square$ & $\square$ & $\square$ \\
\hline Reward based programmes in the organization & $\square$ & $\square$ & $\square$ & $\square$ & $\square$ \\
\hline Future employment relationship within the organization & $\square$ & $\square$ & $\square$ & $\square$ & $\square$ \\
\hline \multicolumn{6}{|c|}{ Psychological Support } \\
\hline Availability of resources to carry out tasks & $\square$ & $\square$ & $\square$ & $\square$ & $\square$ \\
\hline Staff participation in decision making & $\square$ & $\square$ & $\square$ & $\square$ & $\square$ \\
\hline Interaction between staff and work & $\square$ & $\square$ & $\square$ & $\square$ & $\square$ \\
\hline
\end{tabular}




\begin{tabular}{|c|c|c|c|c|c|}
\hline Factors & 5 & 4 & 3 & 2 & 1 \\
\hline $\begin{array}{l}\text { Organization safety measures, risk assessment, norms provided } \\
\text { for staff }\end{array}$ & $\square$ & $\square$ & $\square$ & $\square$ & $\square$ \\
\hline \multicolumn{6}{|l|}{ Financial Support } \\
\hline Salary increment & $\square$ & $\square$ & $\square$ & $\square$ & $\square$ \\
\hline Bonuses and wages provided in the company & $\square$ & $\square$ & $\square$ & $\square$ & $\square$ \\
\hline Profit sharing practices & $\square$ & $\square$ & $\square$ & $\square$ & $\square$ \\
\hline \multicolumn{6}{|c|}{$\begin{array}{l}\text { Section C: Outcomes of increased motivation and commitment } \\
\text { The following questions are based on a } 5 \text { point scale (strongly agree), where } 5 \text { denotes most important and } 1 \\
\text { denotes strongly disagree, with } 3 \text { being neutral. }\end{array}$} \\
\hline Outcomes & 5 & 4 & 3 & 2 & 1 \\
\hline To face competitive market & $\square$ & $\square$ & $\square$ & $\square$ & $\square$ \\
\hline Build enthusiasm in sales staff & $\square$ & $\square$ & $\square$ & $\square$ & $\square$ \\
\hline Regenerate the sales staff interest in work & $\square$ & $\square$ & $\square$ & $\square$ & $\square$ \\
\hline Helps to maintain cooperative work environment & $\square$ & $\square$ & $\square$ & $\square$ & $\square$ \\
\hline Sense of building positive attitude in staff & $\square$ & $\square$ & $\square$ & $\square$ & $\square$ \\
\hline
\end{tabular}

Any other comments

Thank You for your time 